\title{
Impaired Arterial Neointima Formation in Mice with Disruption of the Plasminogen Gene
}

\author{
Peter Carmeliet, ${ }^{\star}$ Lieve Moons, ${ }^{\star}$ Victoria Ploplis, ${ }^{\ddagger}$ Edward Plow, ${ }^{\ddagger}$ and Désiré Collen* \\ *Center for Transgene Technology and Gene Therapy, Flanders Interuniversity Institute for Biotechnology, B-3000 Leuven, Belgium; and \\ ${ }^{*}$ J. Jacobs Center for Thrombosis and Vascular Biology and the Department of Molecular Cardiology, Cleveland Clinic Foundation, \\ Cleveland, Ohio 44195
}

\begin{abstract}
To define the role of plasminogen (Plg) in the smooth muscle cell response after arterial wall injury, neointima formation was evaluated after electric injury of the femoral artery in plasminogen-deficient $\left(\mathrm{Plg}^{-l-}\right)$ mice. The injury destroyed all medial smooth muscle cells, denuded the injured segment of intact endothelium, and induced transient platelet-rich mural thrombosis. In wild-type $\left(\mathrm{Plg}^{+/+}\right)$mice, vascular wound healing was characterized by lysis of the thrombus, transient infiltration of inflammatory cells, and progressive removal of necrotic debris and thrombosis. Topographic analysis revealed repopulation of the media and accumulation in the neointima of smooth muscle cells originating from the noninjured borders, which progressed into the necrotic center. In $\mathrm{Plg}^{-1-}$ mice, wound healing was significantly impaired with delayed removal of necrotic debris, reduced leucocyte infiltration and smooth muscle cell accumulation, and decreased neointima formation. Smooth muscle cells accumulated at the uninjured borders, but failed to migrate into the necrotic center. Proliferation of smooth muscle cells was not affected by Plg deficiency. Evans blue staining revealed no genotypic differences in reendothelialization. Thus, Plg plays a significant role in vascular wound healing and arterial neointima formation after injury, most likely by affecting cellular migration. (J. Clin. Invest. 1997. 99:200-208.) Key words: plasminogen • neointima • restenosis $\bullet$ wound healing $\bullet$ transgenic mice
\end{abstract}

\section{Introduction}

Vascular reconstructions including balloon angioplasty, stenting, and bypass surgery are widely used to treat patients with ischemic heart disease. However, chronic narrowing of the lumen (restenosis) significantly limits the usefulness of such procedures and necessitates costly reintervention $(1,2)$. Although vascular remodeling appears to be a major determinant of luminal stenosis after balloon angioplasty, intimal thickening can contribute to the luminal narrowing, especially when vascular

Address correspondence to Désiré Collen, Center for Transgene Technology and Gene Therapy, Flanders Interuniversity Institute for Biotechnology, Campus Gasthuisberg, KU Leuven, Herestraat 49, B-3000 Leuven, Belgium. Phone: 32-16-345772; FAX: 32-16-345990.

Received for publication 16 July 1996 and accepted in revised form 2 October 1996.

J. Clin. Invest.

(C) The American Society for Clinical Investigation, Inc.

0021-9738/97/01/200/09 \$2.00

Volume 99, Number 2, January 1997, 200-208 remodeling is prevented by placement of intraluminal stents. One hypothesis is that intimal thickening is similar to a wound healing process of the vessel wall after injury, in which smooth muscle cells in the media proliferate, migrate from the media across the internal elastic membrane underneath the endothelium, proliferate in the neointima, and deposit extracellular matrix (3-5). Recent indirect evidence suggests an involvement of proteinases, including the plasminogen and metalloproteinase systems, in the process of smooth muscle cell migration (6-13).

The plasminogen system is composed of an inactive proenzyme, plasminogen, that is converted to its active derivative plasmin by two physiological plasminogen activators (PAs), tissue-type PA (t-PA), and urokinase-type PA (u-PA) (14). Their action is controlled by plasminogen activator inhibitors (PAIs), of which PAI-1 appears to be the predominant physiological inhibitor (14). Whereas t-PA is primarily involved in clot dissolution, u-PA, which binds to a membrane-anchored glycoprotein (u-PAR), has been implicated in pericellular proteolysis during cell migration or tissue remodeling $(15,16)$. Plasmin has been implicated in tissue remodeling during wound healing and inflammation via proteolysis of extracellular matrix components and via activation or liberation of growth factors from the matrix, such as latent TGFß, basic fibroblast growth factor, IL- $1 \beta$, hepatocyte growth factor, and vascular endothelial growth factor $(17,18)$. In several human inflammatory disorders of the lung, kidney, and skin, reduced plasmin proteolysis has been associated with thrombosis, excessive matrix deposition, and impaired wound healing, suggesting that plasmin promotes wound healing (19-21). These observations in patients have recently been extended by gene targeting studies in mice, which have revealed a significant role for the plasminogen system in experimental wound healing in the lung (22), skin (23), and kidney (24). However, the role of plasmin during vascular wound healing after vessel wall injury in vivo has not been examined to date.

In an uninjured artery, t-PA production by quiescent endothelial cells may promote vascular patency, whereas PAI-1 synthesis by medial smooth muscle cells has been proposed to provide a hemostatic barrier $(25,26)$. After injury, expression of t-PA, u-PA, and u-PAR by smooth muscle, endothelial, and inflammatory cells is significantly induced, suggesting that a hyperfibrinolytic response may participate in the migration and/or proliferation of these cells (6-10, 27-29). Indeed, smooth muscle cells use proteinases to degrade the extracellular matrix that encages and prevents them from migration into

1. Abbreviations used in this paper: bFGF, basic fibroblast growth factor; BrdU, 5'-bromo-2'-deoxyuridine; PA, plasminogen activator; PAI, PA inhibitor; t-PA, tissue-type PA; u-PA, urokinase-type PA; u-PAR, urokinase receptor. 
the wound (1-11). Plasmin may trigger this process since it can directly degrade fibrin and matrix and also activate other matrix-degrading proteinases, including the metalloproteinases and heparanases (17). Indirect evidence has been provided that the plasminogen system participates in vascular wound healing and neointima formation in several species, including humans (Carmeliet, P., L. Moons, M. Dewerchin, R.C. Mulligan, R.D. Gerard, and D. Collen, manuscript submitted for publication) (30-32). Since expression of the plasminogen system has also been demonstrated in smooth muscle cells and leukocytes in human atherosclerotic plaques (33-36), normal as well as atherosclerotic or restenotic vessels are able to express those components of the plasminogen system required for controlled plasmin proteolysis after vascular injury. Direct genetic proof for a causal role of the plasminogen system in smooth muscle and endothelial cell function has, however, not been demonstrated. This study in mice with inactivation of the gene encoding plasminogen $\left(\mathrm{Plg}^{-1-}\right)$ (37) demonstrates a significant role of plasmin proteolysis in arterial neointima formation via regulation of smooth muscle cell migration, but not in reendothelialization.

\section{Methods}

Electric injury model and morphometric analysis. Perivascular electric injury and analysis of neointima was performed as described else- where (38). Briefly, femoral arteries from 6-8-wk-old mice were exposed by blunt-end dissection and injured by electric current $(1.4 \mathrm{~V}$ for $2 \mathrm{~s}$ ) using a bipolar microcoagulator (Elektrotom 80B; Martin, Tüttlingen, Germany). The current was delivered through the tips of microforceps (200- $\mu \mathrm{m}$ wide; Fisher, Freiburg, Germany) positioned around the artery without applying mechanical pressure to the vessel, at distances of $1 \mathrm{~mm}$ over a total length of 2-3 mm. This model of acute perivascular electric injury thus differs from the chronic electric stimulation models previously described to induce neointima formation (39). At selected times after injury, the mice were perfusionfixed with $4 \%$ phosphate-buffered formalin $(\mathrm{pH} \mathrm{7.0)}$ at physiological pressure for a period of $10 \mathrm{~min}$. The injured vessel segments were dissected, postfixed in $4 \%$ formalin for $4 \mathrm{~h}$, and either paraffin-embedded or transferred to cold phosphate-buffered saline containing increasing concentrations of sucrose $(5,10$, and $20 \%$ final concentration) overnight. The vessel segments were then embedded in OCTcompound (Tissue-Tek, Miles, Elkhart, IN), snap-frozen in precooled 2-methyl butane, and stored at $-80^{\circ} \mathrm{C}$ until further use.

$7-\mu \mathrm{m}$-thick sections were made throughout the whole dissected segment and stained either with hematoxylin-eosin or the appropriate antiserum, as described below. Smooth muscle cells and inflammatory cells were immunostained using, respectively, a cross-reacting biotinylated murine monoclonal antibody against human smooth muscle alpha-actin (clone 1A4; Sigma Chemical Co., St. Louis, MO; diluted 1:500) and a biotinylated rat monoclonal antibody against murine common leukocyte antigen/CD45 (clone 30F11.1; PharMingen, San Diego, CA; diluted 1:100), followed by peroxidase-labeled avidin (DAKOPATTS, Copenhagen, Denmark). Replication was determined by labeling cells in S-phase with three doses of 5'-bromo-2'-

$$
\text { Plg }+/+
$$

Uninjured
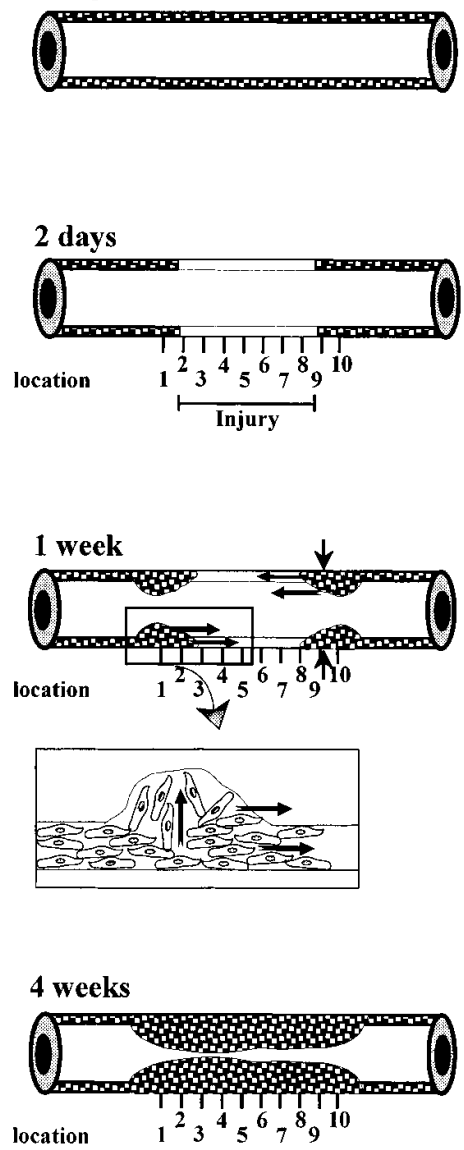

\section{Plg $-/-$}

Uninjured

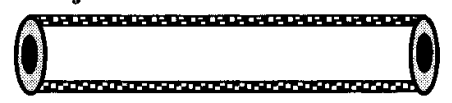

2 days

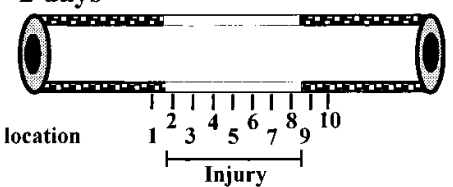

1 week

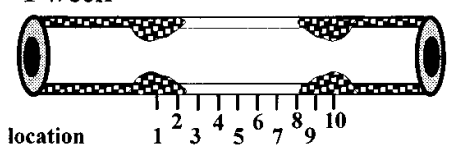

4 weeks

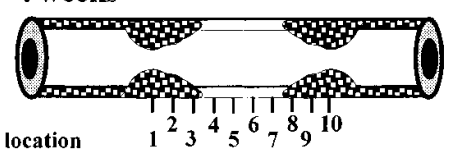

Figure 1. Schematic representation of the wound healing response to vascular injury and the topographic pattern of neointima formation in $\mathrm{Plg}^{+/+}$(left) and $\mathrm{Plg}^{-/-}$ (right) arteries. The media of an uninjured mouse femoral artery consists of two to three layers of smooth muscle cells, but there are no smooth muscle cells in the intima. $2 \mathrm{~d}$ after injury, the injured segment in the media is depleted of smooth muscle cells. Within $1 \mathrm{wk}$ after injury, cells repopulate the media and a small neointima is formed at the borders of the injury in $\mathrm{Plg}^{+/+}$but less in $\mathrm{Plg}^{-/-}$arteries. The insert shows the presumed migration of smooth muscle cells across the internal elastic lamina, within the media, and alongside the lumen. For the sake of clarity, endothelial cells and leukocytes are not represented. Within 2-3 wk after injury, the media is repopulated and the neointima has uniformly developed throughout the whole injured region in $\mathrm{Plg}^{+/+}$arteries, whereas only a smaller neointima is present at the borders of the injury in $\mathrm{Plg}^{-1-}$ arteries. The vertical lines below each artery denote the equally spaced locations that were used for the topographic analysis in Tables III and IV. 
deoxy-uridine $(\mathrm{BrdU})(50 \mathrm{mg} / \mathrm{kg})$ injected intraperitoneally at 17,9 , and $1 \mathrm{~h}$ before killing. Arteries were then perfusion fixed as described above. Sections were stained employing a monoclonal rat anti-BrdU antibody (clone BU1/75; Sera-lab, Sussex, UK; diluted 1:5), followed by biotinylated rabbit anti-rat immunoglobulins (DAKOPATTS; diluted 1:400) and peroxidase-labeled avidin (DAKOPATTS). Peroxidase activity was developed by incubating sections in $0.05 \mathrm{M}$ Tris- $\mathrm{HCl}$ buffer, $\mathrm{pH} 7.0$, containing $0.06 \%$ 3,3'-diaminobenzidine and $0.01 \%$ $\mathrm{H}_{2} \mathrm{O}_{2}$ followed by counterstaining.

Morphometric measurements of cross-sectional areas and cell counts were performed in a blinded manner on transverse sections of artery using a computer-assisted image analysis system (IP Plus 1.0; CN Rood, Zellik, Belgium). For determination of the morphometric averages per experimental group (cross-sectional areas and cell counts), five sections, equally spaced across the injured segment and $>400 \mu \mathrm{m}$ apart (i.e., at locations 1,3 , and 5 or 6,8 , and 10 , depicted beneath each schematically represented artery in Fig. 1) were analyzed, and the averaged measurements per artery were then used to determine the mean \pm SEM of the indicated number of arteries. For the topographic analysis, measurements at similar relative positions throughout the injury (i.e., at locations 1 to 10 for determination of luminal stenosis and at locations 1,5 , and 10 for determination of cell counts) were used to calculate the topographic mean \pm SEM at each position in the different arteries. The incidence and extent of thrombosis was semiquantitatively evaluated by counting the fraction of sections of the injury without or with a mural thrombus (usually occluding the lumen for $<25 \%$ ). Statistical differences between groups were calculated by analysis of variance.

For zymographic analysis of plasminogen activator activities in arteries or thioglycollate-stimulated macrophages (40), tissues or cells were extracted in buffer containing $10 \mathrm{mM}$ sodium phosphate, $\mathrm{pH}$ 7.2, $150 \mathrm{mM}$ sodium chloride, $1 \%$ Triton $\mathrm{X}-100,0.1 \%$ SDS, $0.5 \%$ sodium deoxycholate, and $0.2 \%$ sodium azide. $10 \mu \mathrm{g}$ (artery) and $30 \mu \mathrm{g}$ (macrophage) protein extracts were then electrophoresed on a $12.5 \%$ acrylamide gel, cast with $1 \%$ nonfat dry milk and $5 \mu \mathrm{g} / \mathrm{ml}$ human plasminogen under nonreducing, denaturing conditions, washed twice at room temperature in $2.5 \%$ Triton $\mathrm{X}-100$ (dissolved in water), followed by overnight incubation at $37^{\circ} \mathrm{C}$ in buffer containing $100 \mathrm{mM}$ glycine, $\mathrm{pH}$ 8.0. Gels were stained in $0.5 \%$ Coomassie Brilliant Blue R250 and destained in buffer containing $45 \%$ ethanol and $10 \%$ acetic acid. The amount of lysis (area $\times$ intensity) was quantitatively analyzed using the Quantimed 600 image analysis software and expressed in arbitrary units lysis. For zymographic analysis of plasminogen activator activities in the plasma, $200 \mu$ l plasma (collected on 0.1 vol of $4 \%$ trisodium citrate) was precipitated and transferred on fibrin plates and incubated at $37^{\circ} \mathrm{C}$ until lysis as previously described (41). Plasma samples were compared relative to a murine t-PA and u-PA standard (40). The fraction of the lysis due to t-PA or u-PA activity was determined by including in the fibrin gel $20 \mu \mathrm{g} / \mathrm{ml}$ polyclonal rabbit anti-murine t-PA- and/or u-PA-specific IgGs, respectively. Lysis was expressed as units murine plasminogen activator per milliliter plasma.

\section{Results}

Electric injury and vascular wound healing in wild-type $\left(\mathrm{Plg}^{+/+}\right)$ mice. To perform a genetic analysis of the molecular mechanisms involved in vascular wound healing, a model to injure arteries in mice was developed and characterized in detail else-
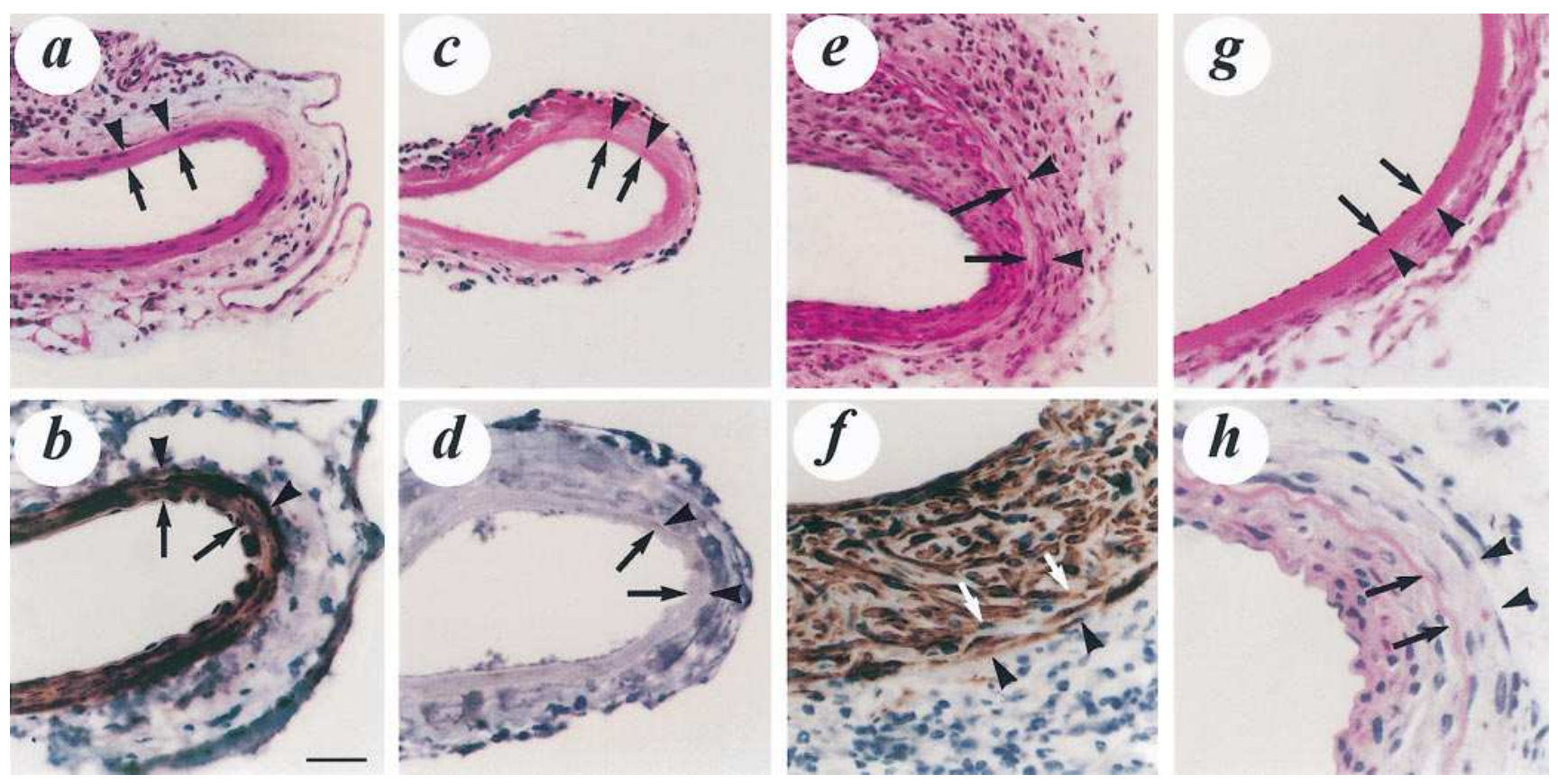

Figure 2. Light microscopic analysis of vascular wound healing and neointima formation after electric injury. ( $a$ and $b)$ Sections through an uninjured artery from a $\mathrm{Plg}^{+/+}$mouse, stained with hematoxylin-eosin $(a)$, or immunostained for smooth muscle cell $\alpha$-actin $(b)$, revealing the presence of two to three layers of smooth muscle cells in the media and a single layer of endothelial cells in the intima. ( $c$ and $d$ ) Sections through an artery of a Plg ${ }^{+/+}$mouse (at location 5 according to the locations defined in Fig. 1) $2 \mathrm{~d}$ after injury stained with hematoxylin-eosin (c), or immunostained for smooth muscle $\alpha$-actin $(d)$, revealing necrosis across the vessel wall. The media is acellular and contains eosinophilic debris. $(e$ and f) Sections through an artery from a $\mathrm{Plg}^{+/+}$mouse (location 5) $3 \mathrm{wk}$ after injury, stained with hematoxylin-eosin $(e)$, or immunostained for smooth muscle $\alpha$-actin $(f)$, revealing a multilayered smooth muscle cell-rich neointima. $(g$ and $h)$ Sections through an artery from a Plg ${ }^{-1-} \mathrm{mouse}^{-}$ $3 \mathrm{wk}$ after injury, stained with hematoxylin-eosin, revealing a necrotic and acellular media (suggesting impaired wound healing) in the central region of the injured segment $(g)$ (location 5), and a small neointima at the borders $(h)$ (location 1 or 10$)$ of the injury. The arrows indicate the internal elastical lamina; the arrowheads denote the external elastic lamina. Magnification: the bar represents $43 \mu \mathrm{m}$ in $a-f$, and $h$, and $21 \mu \mathrm{m}$ in $g$. 
where (38). Since the electric injury model differs from the more widely used mechanical injury model in mouse (42) and rat $(43,44)$, its characteristics are briefly discussed. Fig. 1 schematically represents the healing response and neointima formation that occurred after a single perivascular application of an electric current that denuded the endothelium and destroyed most or all smooth muscle cells in the media (38). As shown in Fig. 2, $a$ and $b$, the media but not the intima of an uninjured artery from a wild-type mouse contains smooth muscle $\alpha$-actin immunoreactive cells. Within $2 \mathrm{~d}$ after injury, significant cell necrosis across the vessel wall occurred as revealed by the acellular media and eosinophilic debris (Fig. 2, $c$ and $d$ ). This resulted in a vascular wound healing response that is characterized by transient mural thrombosis and infiltration of inflammatory cells, removal of necrotic debris, reendothelialization, repopulation of the damaged media by smooth muscle cells, and the formation of a neointima containing up to 12 layers of smooth muscle $\alpha$-actin immunoreactive cells (Fig. 2, $e$ and $f$ ) (38). Wound healing and the associated arterial neointima formation and reendothelialization initiated at the uninjured borders with subsequent progression into the necrotic center. This healing process is similar to that observed after venous grafts $(45,46)$, laser-induced thermal injury (47), necrotizing transluminal ligation injury (48), and end-to-end microvascular anastomosis (49).

Vascular wound healing and arterial neointima formation in mice with inactivation of the Plg gene $\left(\mathrm{Plg}^{-1-}\right)$. Vascular wound healing was significantly impaired in $\mathrm{Plg}^{-/-}$arteries (Fig. 2, $g$ and $h$ ). Removal of the necrotic debris, repopulation of the media by smooth muscle cells, and leucocyte infiltration of the media appeared to be delayed during the first week after injury. In fact, acellular regions of necrotic debris, similar to those observed within $2 \mathrm{~d}$ after injury in $\mathrm{Plg}^{+/+}$mice (Fig. $2 c$ ), were still present in the central region of the media of the injured segment beyond $2 \mathrm{wk}$ after injury (Fig. $2 g$ ). A neointima was present at the uninjured borders beyond $1 \mathrm{wk}$ after injury, but was significantly smaller, contained fewer cells, and progressed less into the necrotic center as compared with $\mathrm{Plg}^{+/+}$ arteries (Fig. $2 g$ ).

Neointima formation, as deduced from measuring the

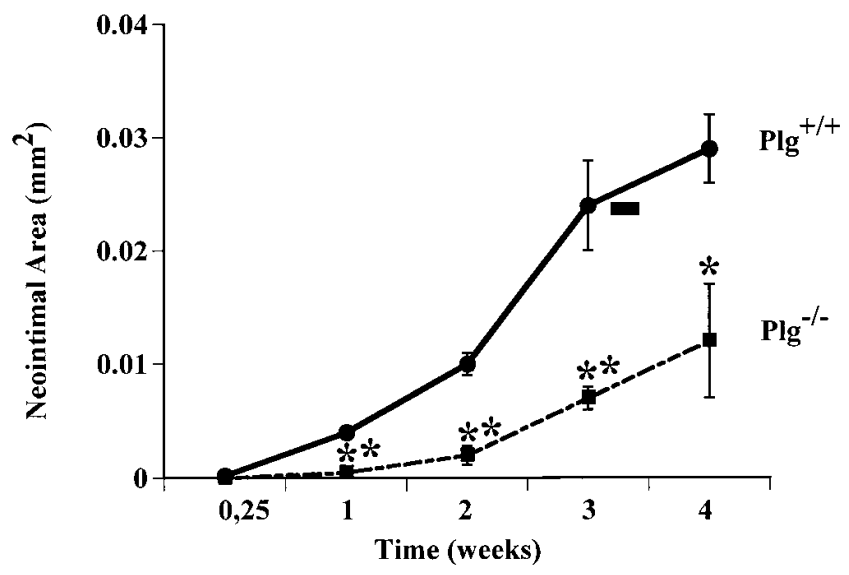

Figure 3. Morphometric analysis of the cross-sectional neointimal area in $\mathrm{Plg}^{+/+}$and $\mathrm{Plg}^{-/-}$mice at the indicated times after electric injury. Neointima formation was greatly reduced and delayed in $\mathrm{Plg}^{-/-}$ mice. $* P<0.01$ and $* * P<0.001$ vs. wild type by analysis of variance. $\mathrm{Plg}^{+/+}$, wild type; $\mathrm{Plg}^{-/-}, \mathrm{Plg}$ deficient.
Table I. Cell Accumulation in the Media and Neointima in $\mathrm{Plg}^{+/+}$and $\mathrm{Plg}^{-1-}$ Arteries

\begin{tabular}{clllll}
\hline & & \multicolumn{4}{c}{ Time after injury (in wk) } \\
\cline { 3 - 6 } Cells & Genotype & \multicolumn{1}{c}{1} & \multicolumn{1}{c}{2} & \multicolumn{1}{c}{3} & 4 \\
\hline \multirow{2}{*}{ Neointima } & $\mathrm{Plg}^{+/+}$ & $87 \pm 8^{*}(11)$ & $126 \pm 8(8)$ & $149 \pm 20(8)$ & $162 \pm 24(7)$ \\
& $\mathrm{Plg}^{-/-}$ & $28 \pm 7^{\ddagger}(13)$ & $38 \pm 11^{\ddagger}(10)$ & $25 \pm 3^{\ddagger}(7)$ & $58 \pm 9^{\ddagger}(7)$ \\
Media & $\mathrm{Plg}^{+/+}$ & $28 \pm 5(11)$ & $59 \pm 9(12)$ & $59 \pm 8(7)$ & $53 \pm 4(11)$ \\
& $\mathrm{Plg}^{-/-}$ & $10 \pm 2^{\ddagger}(13)$ & $18 \pm 3^{\ddagger}(10)$ & $15 \pm 4^{\ddagger}(7)$ & $33 \pm 7^{\ddagger}(7)$
\end{tabular}

* Nuclear cell counts were performed on five sections per artery equally spaced throughout the injury, which were then averaged. The values represent the mean \pm SEM of these averages, with the number of arteries indicated in brackets. ${ }^{\ddagger} P<0.05 \mathrm{vs}$. $\mathrm{Plg}^{-/-}$by analysis of variance.

cross-sectional area within the internal elastic lamina (Fig. 3) and from counting of the neointimal cells (Table I), was significantly reduced in $\mathrm{Plg}^{-/-}$mice. A similar reduction in the number of medial cells was observed in $\mathrm{Plg}^{-1-}$ arteries (Table I). Leukocytes, which transiently infiltrated the media and neointima during the first week (38), appeared to accumulate in smaller numbers in $\mathrm{Plg}^{-/-}$than in $\mathrm{Plg}^{+/+}$arteries: $38 \pm 6 \%$ of medial and $38 \pm 4 \%$ of neointimal cells were CD 45 -immunoreactive leukocytes in $\mathrm{Plg}^{+/+}$arteries, whereas only $3 \pm 3 \%$ of medial and $13 \pm 3 \%$ of neointimal cells were CD45 positive in $\mathrm{Plg}^{-1-}$ arteries (each $P<0.005$ vs. $\mathrm{Plg}^{+/+}$by analysis of variance). Since most (>97\%, excluding the endothelial cells) neointimal and medial cells beyond 2 wk were $\alpha$-actin-positive smooth muscle cells (38), accumulation of smooth muscle cells in $\mathrm{Plg}^{-/-}$arteries was also significantly decreased.

Proliferation of smooth muscle cells. To evaluate whether deficiency of plasminogen affects cellular proliferation, incorporation of BrdU into replicating cells was determined on five sections per artery in the indicated number of arteries (Table II). Proliferation of (intimal) smooth muscle cells after electric injury was delayed and reduced by comparison with mechanical injury (38). As shown in Table II, medial and neointimal cell proliferation were not significantly different between $\mathrm{Plg}^{+/+}$

Table II. Proliferation (in Percent) of Medial and Neointimal Cells in $\mathrm{Plg}^{+/+}$and $\mathrm{Plg}^{-/-}$Arteries

\begin{tabular}{lcccc}
\hline & \multicolumn{4}{c}{ Time after injury (in wk) } \\
\cline { 2 - 5 } & 1 & 2 & 3 & 4 \\
\hline $\begin{array}{l}\text { Neointimal cells } \\
\quad \operatorname{Plg}^{+/}\end{array}$ & $14 \pm 3^{*}(12)$ & $15 \pm 4(11)$ & $8 \pm 4(8)$ & $0.5 \pm 0.5(5)$ \\
$\quad \mathrm{Plg}^{-/-}$ & $12 \pm 3(11)$ & $8 \pm 2(8)$ & $4 \pm 2(7)$ & $0.9 \pm 0.6(7)$ \\
Medial cells & & & & \\
$\quad \mathrm{Plg}^{-/+}$ & $7 \pm 2(11)$ & $8 \pm 2(12)$ & $5 \pm 2(12)$ & $0.5 \pm 0.3(8)$ \\
$\mathrm{Plg}^{-/-}$ & $6 \pm 2(12)$ & $2 \pm 1^{\ddagger}(9)$ & $0.1 \pm 0.1(7)$ & $0.1 \pm 0.1(9)$
\end{tabular}

*Proliferation of medial and neointimal cells was quantified by counting the number of BrdU-positive nuclei on five equally spaced sections per artery across the injured segment, which were then averaged per artery. The values represent the mean \pm SEM of these averages with the number of arteries indicated in brackets. $\mathrm{Plg}^{+/+}$, wild type; $\mathrm{Plg}^{-/-}$, $\mathrm{Plg}$ deficient. ${ }^{\ddagger} P<0.05$ vs. $\mathrm{Plg}^{+/+}$by analysis of variance. No other statistically significant differences between both genotypes were found. 

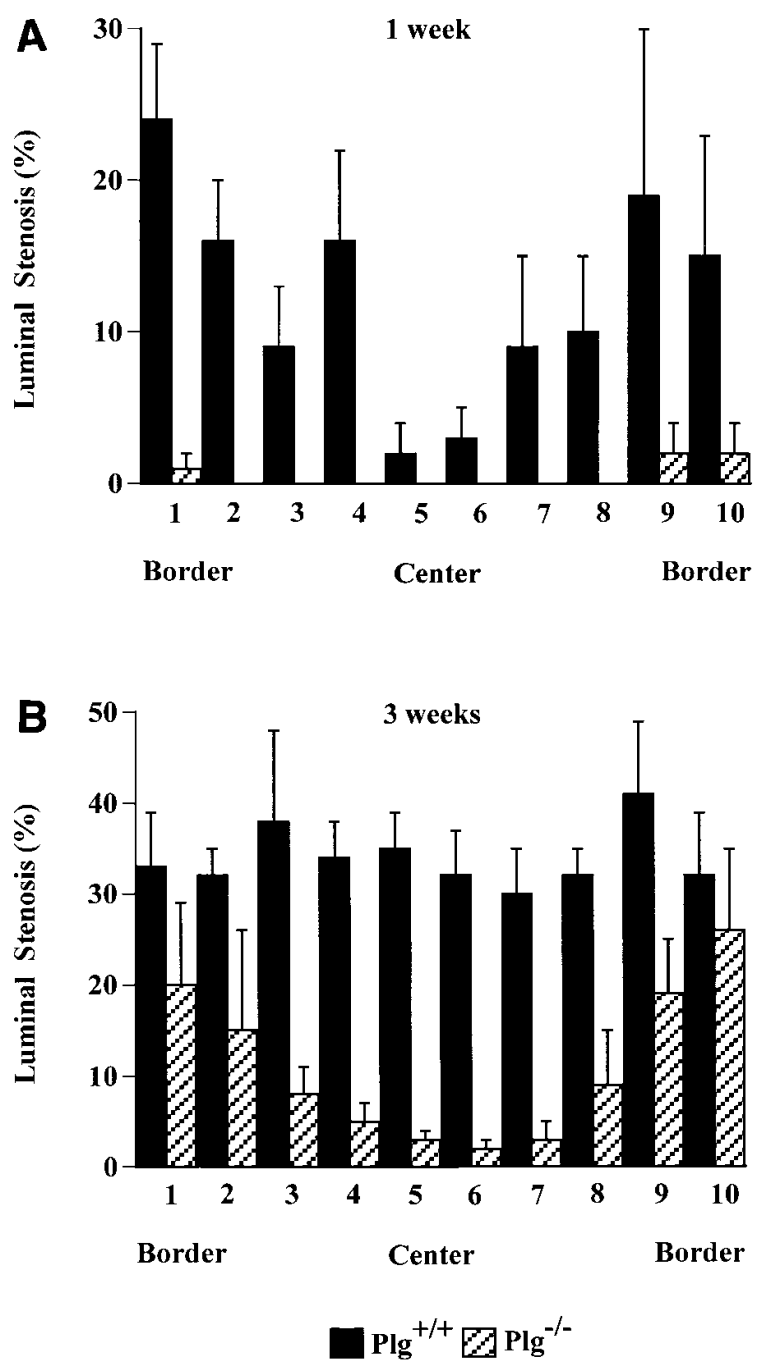

\section{Locations across the injured segment}

Figure 4. Topographic analysis of the arterial neointima formation in $\mathrm{Plg}^{+/+}$and $\mathrm{Plg}^{-/-}$arteries within 1 and 3 wk after injury. Within $1 \mathrm{wk}$ after injury, significant neointima formation initiates from the uninjured borders in the $\mathrm{Plg}^{+/+}$arteries and only minimally in the $\mathrm{Plg}^{-1-}$ arteries $\left(P<0.05\right.$ vs. $\mathrm{Plg}^{+/+}$by analysis of variance). Within $3 \mathrm{wk}$ after injury, a significant neointima has formed across the entire injured segment in the $\mathrm{Plg}^{+/+}$arteries, whereas a neointima is present only at the borders of the injured segment in the $\mathrm{Plg}^{-/-}$arteries $(P<0.05 \mathrm{vs}$. $\left.\mathrm{Plg}^{+/+}\right)$. The data represent the mean \pm SEM of the morphometric measurements in at least seven arteries, determined at similar relative topographic locations throughout the injured segment. The number of the relative locations throughout the injured segment refers to those defined in Fig. 1 beneath each schematically represented artery.

and $\mathrm{Plg}^{-/-}$arteries, except for a somewhat lower proliferation rate of medial smooth muscle cells in $\mathrm{Plg}^{-/-}$arteries at 2 wk after injury.

Migration of smooth muscle cells. Smooth muscle cells after electric injury migrated within the media and alongside the lumen from the uninjured borders into the necrotic center (38). This process was quantitated by measuring the luminal narrowing (percent stenosis) and cell accumulation at equally spaced positions across the injured segment. Within $1 \mathrm{wk}$ after injury, a significant neointima was initiated at the borders of
Table III. Topographic Pattern of Medial Cell Repopulation

\begin{tabular}{llccc}
\hline & & \multicolumn{3}{c}{ Topographic location across injury } \\
\cline { 3 - 5 } $\begin{array}{c}\text { Time after } \\
\text { injury }\end{array}$ & Genotype & $\begin{array}{c}\text { Border } \\
\text { (position 1) }\end{array}$ & $\begin{array}{c}\text { Center } \\
\text { (position 5) }\end{array}$ & $\begin{array}{c}\text { Border } \\
\text { (position 10) }\end{array}$ \\
\hline $1 \mathrm{wk}$ & $\mathrm{Plg}^{+/+}$ & $53 \pm 7$ & $8 \pm 3^{*}$ & $58 \pm 5$ \\
& $\mathrm{Plg}^{-/-}$ & $64 \pm 9$ & $12 \pm 5^{*}$ & $58 \pm 5$ \\
$3 \mathrm{wk}$ & $\mathrm{Plg}^{+/+}$ & $62 \pm 7$ & $47 \pm 6$ & $72 \pm 5$ \\
& $\mathrm{Plg}^{-/-}$ & $54 \pm 10$ & $3 \pm 2^{*}$ & $49 \pm 12$
\end{tabular}

The data represent the mean \pm SEM of the number of cells in at least seven arteries, determined at similar relative topographic locations throughout the injured arterial segment. The topographic locations are indicated on the schematically represented arteries in Fig. $1 .{ }^{*} P<0.05$ vs. uninjured border (positions 1 or 10) by analysis of variance.

the injury in $\mathrm{Plg}^{+/+}$arteries, but only minimally in $\mathrm{Plg}^{-/-}$arteries $\left(P<0.05 \mathrm{vs}\right.$. $\mathrm{Plg}^{+/+}$by analysis of variance) (Fig. 4$)$. Within 3 wk after injury, the neointima had progressed into the center of the injury in $\mathrm{Plg}^{+/+}$arteries, whereas the neointima in $\mathrm{Plg}^{-/-}$ arteries failed to progress to the same extent into the necrotic center as in $\mathrm{Plg}^{+/+}$arteries $\left(P<0.05 \mathrm{vs} \mathrm{Plg}^{+/+}\right.$by analysis of variance) (Fig. $4 \mathrm{~B}$ ). These findings were extended by counting the medial and neointimal cell nuclei at three equally spaced positions across the injured segment (locations 1, 5, and 10 in the arteries of Fig. 1), revealing accumulation of cells at the borders but reduced progression into the center of the injured segment (Tables III and IV). Thus, these data suggest that smooth muscle cells migrate over a shorter distance in $\mathrm{Plg}^{-1-}$ than in $\mathrm{Plg}^{+/+}$arteries. This process is schematically represented in Fig. 1.

Reendothelialization. Electric injury completely denuded the injured segment of intact endothelium as revealed by Evans blue staining immediately after injury (Fig. $5 a$ ). Reendothelialization initiated from the uninjured borders into the necrotic center and was complete within 2 wk after injury in $\mathrm{Plg}^{+/+}$mice (Fig. $5 \mathrm{a}$ ). Endothelial regrowth was, however, not affected in either its extent or its rate by Plg deficiency as compared with wild-type mice ( $P=\mathrm{NS}$ ) (Fig. 5).

Table IV. Topographic Pattern of Neointimal Cell Accumulation

\begin{tabular}{lcccr}
\hline & & \multicolumn{3}{c}{ Topographic location across injury } \\
\cline { 3 - 5 } $\begin{array}{c}\text { Time after } \\
\text { injury }\end{array}$ & Genotype & $\begin{array}{c}\text { Border } \\
\text { (position 1) }\end{array}$ & $\begin{array}{c}\text { Center } \\
\text { (position 5) }\end{array}$ & $\begin{array}{c}\text { Border } \\
\text { (position 10) }\end{array}$ \\
\hline \multirow{2}{*}{$1 \mathrm{wk}$} & $\mathrm{Plg}^{+/+}$ & $124 \pm 29^{*}$ & $47 \pm 14^{\ddagger}$ & $117 \pm 25$ \\
& $\mathrm{Plg}^{-/-}$ & $34 \pm 8$ & $20 \pm 6$ & $39 \pm 10$ \\
$3 \mathrm{wk}$ & $\mathrm{Plg}^{+/+}$ & $184 \pm 47$ & $153 \pm 28$ & $219 \pm 32$ \\
& $\mathrm{Plg}^{-/-}$ & $62 \pm 7$ & $27 \pm 8^{\ddagger \S}$ & $65 \pm 14$
\end{tabular}

*The data represent the mean \pm SEM of the number of neointimal cells in at least seven arteries, determined at similar relative topographic locations at the uninjured borders or throughout the injured arterial segment. ${ }^{\ddagger} P<0.05$ vs. uninjured border (locations 1 and 10 ) by analysis of variance. ${ }^{\S}$ All neointimal cells were counted, including endothelial cells, which constitute the largest fraction of neointimal cells in the center of the $\mathrm{Plg}^{-/-}$arteries. The topographic positions are indicated on the schematically represented arteries in Fig. 1. 

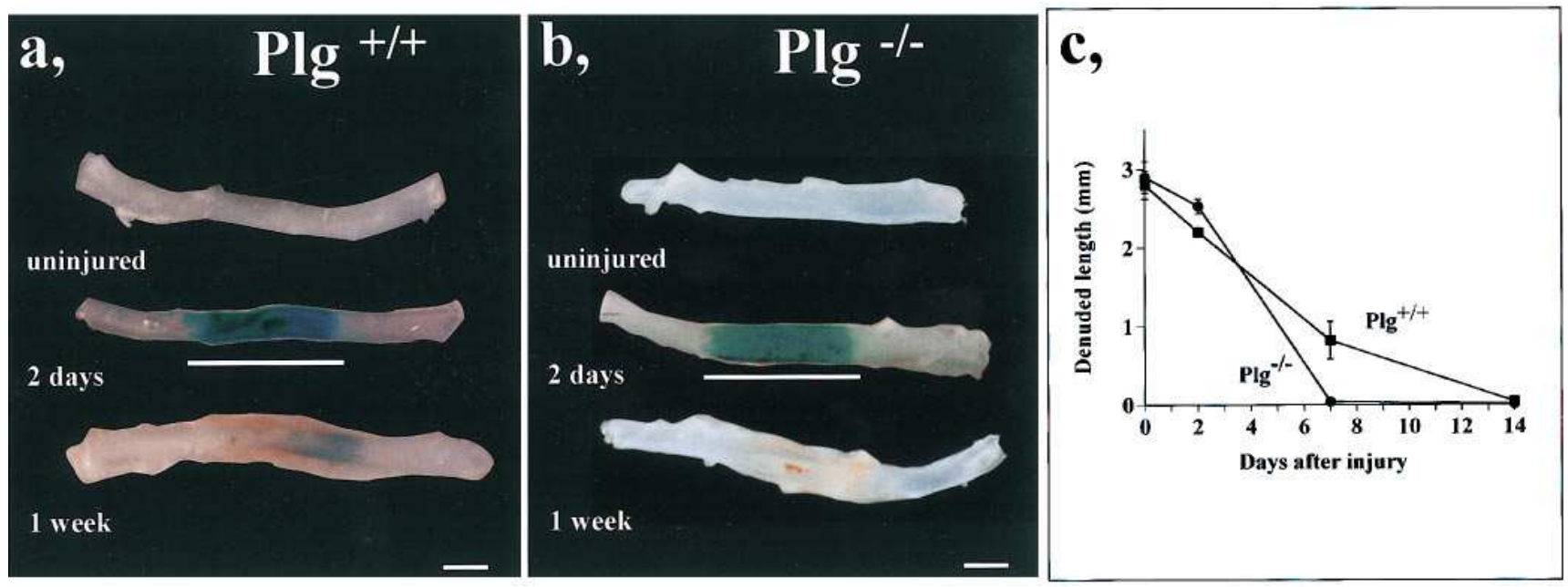

Figure 5. Endothelial regrowth after electric injury. (a) Evans blue staining of uninjured and electrically injured $\mathrm{Plg}^{+/+}$and $\mathrm{Plg}^{-/-}$arteries revealing a white (endothelialized) uninjured artery, a blue (deendothelialized) artery immediately after injury, and the regrowth of the endothelium within $2 \mathrm{wk}$ after injury. The magnification bar represents $519 \mu \mathrm{m}$ in $a$. The white bar underlining the blue-stained segment denotes the distance measured to quantify endothelial regrowth. (b) Quantitative analysis of endothelial regrowth in $\mathrm{Plg}^{+/+}$and $\mathrm{Plg}^{-/-}$arteries at the indicated times after injury, by measuring the Evans blue stained distance. Endothelial cell regrowth occurred at a similar rate in both genotypes. The data represent the mean \pm SEM of measurements in five different arteries.

Thrombosis. Electric injury of $\mathrm{Plg}^{+/+}$arteries results in transient mural thrombosis during the first week after injury; i.e., before the appearance of the first smooth muscle cells in the neointima (38). Since deficiency of Plg results in widespread thrombosis and a greatly reduced ability to spontaneously lyse a ${ }^{125}$ I-fibrin-labeled pulmonary plasma clot (37), the incidence and extent of thrombosis in $\mathrm{Plg}^{-/-}$arteries was semiquantitatively evaluated. As can be seen in Table V, mural thrombosis was observed more frequently and during longer time periods in $\mathrm{Plg}^{-/-}$than in $\mathrm{Plg}^{+/+}$arteries.

Expression of the plasminogen system. Deficiency of u-PA but not of t-PA results in a similar reduction of neointima formation as deficiency of plasminogen (Carmeliet, P., L. Moons, M. Dewerchin, R.C. Mulligan, R.D. Gerard, and D. Collen, manuscript submitted for publication). To investigate whether $\mathrm{u}-\mathrm{PA}$ acts by activation of plasminogen and whether deficiencies of u-PA or Plg would induce a compensatory increase in t-PA, t-PA and u-PA activities were evaluated in the plasma and in the different cell types that participate in vascular wound healing (vascular cells in arteries and macrophages), in

Table V. Mural Thrombosis in Injured Arteries

\begin{tabular}{lccccc}
\hline \multirow{2}{*}{ Time after injury } & \multicolumn{2}{c}{$\mathrm{Plg}^{+/+}$} & & \multicolumn{2}{c}{$\mathrm{Plg}^{-/-}$} \\
\cline { 2 - 3 } \cline { 5 - 6 } Thrombosis & & \multicolumn{2}{c}{ Thrombosis } \\
\hline \multirow{3}{*}{$1 \mathrm{wk}$} & - & + & - & + \\
& $30 / 39$ & $9 / 39$ & & $15 / 35$ & $20 / 35$ \\
$3 \mathrm{wk}$ & $(77 \%)$ & $(23 \%)$ & & $(43 \%)^{*}$ & $(57 \%)^{*}$ \\
& $36 / 36$ & $0 / 36$ & & $22 / 31$ & $9 / 31$ \\
& $(100 \%)$ & $(0 \%)$ & $(71 \%)^{\ddagger}$ & $(29 \%)^{\ddagger}$
\end{tabular}

Data represent the fraction of sections from $\mathrm{Plg}^{+/+}$and $\mathrm{Plg}^{-/-}$arteries without thrombosis $(-)$ or with a mural thrombus $(+)$, usually occluding

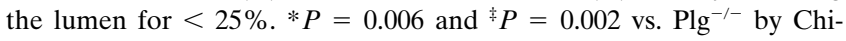
square analysis.
u-PA- and Plg-deficient mice. As can be seen in Fig. 6 and Table VI, there were no differences in t-PA and u-PA activity in the arteries, macrophages, and plasma from wild-type, Plgdeficient, or u-PA-deficient mice. These data indicate that u-PA is expressed in $\mathrm{Plg}^{-1-}$ mice, but is unable to rescue deficiency

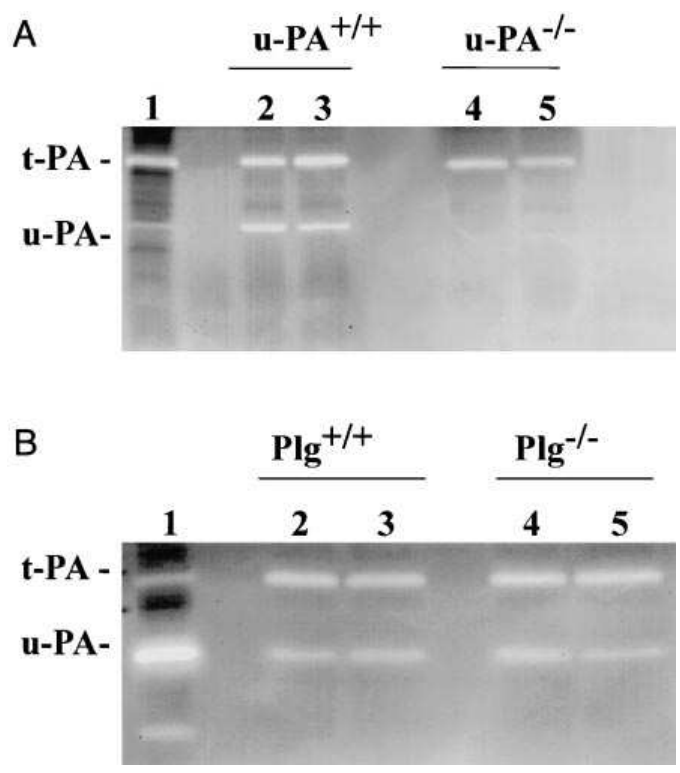

Figure 6. Zymographic analysis of t-PA and u-PA activity. $(A)$ Lysis zones induced by t-PA or u-PA activity in extracts from thioglycollate-stimulated peritoneal macrophages (containing $30 \mu \mathrm{g}$ protein) from two individual u-PA ${ }^{+/+}$mice (lanes 2 and 3 ) and $\mathrm{u}-\mathrm{PA}^{-/-}$mice (lanes 4 and 5). For comparison, lane 1 is a brain extract from a wildtype mouse, containing abundant t-PA. (B) Lysis zones induced by $\mathrm{t}-\mathrm{PA}$ or $\mathrm{u}-\mathrm{PA}$ activity in arterial extracts (containing $10 \mu \mathrm{g}$ protein) from two individual $\mathrm{Plg}^{+/+}$mice (lanes 2 and 3 ) and $\mathrm{Plg}^{-/-}$mice (lanes 4 and 5). For comparison, lane 1 is a kidney extract from a wild-type mouse, containing abundant u-PA. 
Table VI. Plasminogen Activator Activities in Tissue Extracts from $\mathrm{Plg}^{+/+}$and $\mathrm{Plg}^{-/-}$Mice

\begin{tabular}{|c|c|c|c|}
\hline \multirow[b]{2}{*}{ Tissue } & \multirow[b]{2}{*}{ Genotype } & \multicolumn{2}{|c|}{ Lysis } \\
\hline & & $\mathrm{t}-\mathrm{PA}$ & $\mathrm{u}-\mathrm{PA}$ \\
\hline \multirow[t]{3}{*}{ Artery } & Wild type & $1.28 \pm 0.07 *$ & $0.41 \pm 0.10 *$ \\
\hline & $\mathrm{u}-\mathrm{PA}^{-1-}$ & $1.36 \pm 0.07 *$ & No lysis \\
\hline & $\mathrm{Plg}^{-/-}$ & $1.20 \pm 0.05^{*}$ & $0.63 \pm 0.16^{*}$ \\
\hline \multirow[t]{2}{*}{ Macrophages } & Wild type & $1.25 \pm 0.08 *$ & $0.42 \pm 0.10^{*}$ \\
\hline & $\mathrm{Plg}^{-/-}$ & $1.04 \pm 0.08 *$ & $0.69 \pm 0.21 *$ \\
\hline \multirow[t]{2}{*}{ Plasma } & Wild type & $2.27 \pm 0.15^{\ddagger}$ & $20.6 \pm 4.1^{\ddagger}$ \\
\hline & $\mathrm{u}-\mathrm{PA}^{-1-}$ & $3.60 \pm 2.20^{\ddagger}$ & No lysis \\
\hline
\end{tabular}

Data represent mean $\pm \operatorname{SEM}(n=3)$ of lysis (area $\times$ intensity) as determined on zymography gels, *expressed as arbitrary units lysis or as determined on fibrin plates, ${ }^{*}$ expressed as units murine plasminogen activator per milliliter plasma. No statistically significant differences were observed between the different genotyes. $\mathrm{Plg}^{-/-}$, plasminogen deficient; $\mathrm{u}-\mathrm{PA}^{-/-}$, u-PA deficient.

of Plg, suggesting that u-PA acts by activation of Plg. Similarly, the observation that t-PA expression is not affected by deficiency of u-PA or Plg indicates that t-PA is unable to rescue deficiency of u-PA or Plg, suggesting that t-PA is not mediating neointima formation.

\section{Discussion}

Role of the plasminogen system in smooth muscle cell migration. The present study demonstrates that deficiency of plasminogen greatly reduces neointima formation, suggesting that plasmin proteolysis promotes vascular wound healing after injury. These data are consistent with previous findings that expression of t-PA, u-PA, and u-PAR by vascular cells is significantly induced after injury (Carmeliet, P., L. Moons, M. Dewerchin, R.C. Mulligan, R.D. Gerard, and D. Collen, manuscript submitted for publication) (6-10). The increased levels of plasminogen activators may convert plasminogen, which readily gains access to the arterial media after removal of the endothelium, to plasmin in the immediate surroundings of smooth muscle cells and create a hyperfibrinolytic state that is required for proper healing of the wound.

Our data further suggest that smooth muscle cells require increased plasmin proteolysis to migrate into the wound. Indeed, the observations in $\mathrm{Plg}^{-1-}$ mice that neointima formation was reduced, that smooth muscle cells accumulated at the borders but failed to progress into the necrotic center, and that proliferation was only marginally affected suggest that plasminogen deficiency impairs smooth muscle cell migration (see also Fig. 1 for schematic representation). Since smooth muscle cells are surrounded by an encaging extracellular matrix, they can only migrate into the wound by degrading their surrounding matrix using proteinases such as plasmin, metalloproteinases, cathepsins, heparinases, elastases, etc. $(11,13)$. Plasmin appears to play an important role in this process, possibly by triggering activation of other proteinases, which are usually present as inactive proenzymes (17).

In another study, neointima formation was found to be similarly impaired in u-PA-deficient but not in t-PA-deficient mice (Carmeliet, P., L. Moons, M. Dewerchin, R.C. Mulligan, R.D. Gerard, and D. Collen, manuscript submitted for publication). Since expression of u-PA was not affected by Plg deficiency, u-PA by itself is unable to mediate neointima formation in the absence of Plg. Despite normal levels of expression, t-PA is unable to compensate for deficiency of u-PA or Plg.

Taken together, these data indicate that u-PA is the physiologically important plasminogen activator for smooth muscle cell migration and that it acts by plasminogen activation to generate plasmin proteolysis. This hypothesis is consistent with previous reports that the plasmin inhibitor tranexamic acid reduces smooth muscle cell migration in the rat carotid artery without affecting smooth muscle cell proliferation $(8,9)$. Similarly, metalloproteinase inhibitors reduce neointima formation in the ballooned rat carotid artery by impairing migration but not proliferation of smooth muscle cells (12). One interesting but unresolved question is whether smooth muscle cell survival (apoptosis) is affected by plasminogen deficiency, since this may be another mechanism to control neointimal growth.

Smooth muscle cells can control their own migration in an autocrine way since they express t-PA, u-PA, and u-PAR (7, 10, 29, and Carmeliet, P., L. Moons, M. Dewerchin, R.C. Mulligan, R.D. Gerard, and D. Collen, manuscript submitted for publication) and, therefore, would be able to generate pericellular plasmin proteolysis. Alternatively, endothelial or inflammatory cells (which also accumulate in the wound; this study and references 1-3,47) may assist in the migration of smooth muscle cells by providing u-PA to the smooth muscle cells (similar to the paracrine regulation of tumor cell migration by stromal cells; reference 16) or by "clearing a path" for them. Whatever the cellular interactions, activation of the plasminogen system within the vessel wall after injury appears to participate in the wound healing response in vivo.

Role of plasmin in smooth muscle cell proliferation. No consistent significant differences in smooth muscle cell proliferation were observed between $\mathrm{Plg}^{-/-}$and $\mathrm{Plg}^{+/+}$arteries, except for a somewhat reduced proliferation rate of $\mathrm{Plg}^{-1-}$ medial smooth muscle cells after $2 \mathrm{wk}$. The latter might be attributable to the ability of plasmin to modulate the activation or liberation from the extracellular matrix of certain growth factors (including basic fibroblast growth factor, TGFß, and IL-1) (17, 18), which have been implied in growth control after mechanical injury $(3,5)$, which would be reduced in $\mathrm{Plg}^{-1-}$ mice.

Role of plasmin in matrix remodeling. Studies on the role of the plasminogen system during lung, skin, and kidney injury in mice have revealed that impaired plasmin proteolysis results in increased accumulation of extracellular matrix containing fibrin, collagen, and fibronectin (18-24). Electron microscopy of electrically injured media in wild-type mice has revealed that the media consists of necrotic smooth muscle cell remnants embedded in a fibrin-rich extracellular matrix (38). Thus, healing of the necrotic media must involve proteolytic degradation and removal of this debris. Our studies indicate that removal of the necrotic debris was significantly impaired in $\mathrm{Plg}^{-1-}$ arteries, indicating that plasmin proteolysis is indeed required for appropriate tissue remodeling during wound healing. Thus, the deposited matrix may constitute a barrier for the infiltrating leukocytes (which assist in clearance of the debris) and the migrating smooth muscle cells.

Role of plasmin in thrombosis. Deficiency of plasminogen results in severe thrombosis with impaired ability to lyse an ex- 
perimental pulmonary plasma clot in vivo (37). The present findings confirm the increased susceptibility of $\mathrm{Plg}^{-/-}$mice for thrombosis after vascular injury. Thrombosis may promote neointima formation by providing a provisional matrix for smooth muscle cell migration and supplying a variety of growth factors, able to modulate proliferation and migration of smooth muscle cells (1-5). Interestingly, neointima formation was smaller but thrombosis more persistent in $\mathrm{Plg}^{-1}$ arteries, suggesting that the presence of a mural thrombus was not sufficient and even may have impeded neointima formation in $\mathrm{Plg}^{-1-}$ arteries. In fact, our data imply that, despite a more persistent thrombus, $\mathrm{Plg}^{-/-}$cells fail to migrate into and lyse the thrombus. A similar mechanism of increased extracellular matrix deposition and deficient keratinocyte migration was proposed for the impaired skin wound healing in $\mathrm{Plg}^{-1-}$ mice (23).

Role of plasmin in endothelial cell regeneration. Endothelial cell regrowth was not impaired by plasminogen deficiency. This is somewhat surprising in view of the induced expression of plasminogen activators in regenerating endothelium in vivo and in vitro after injury (15). However, to date, no abnormalities in vascular development have been described in mice with inactivated genes of plasminogen system components during embryogenesis (50), suggesting a redundant role for the plasminogen system and/or compensation by other proteinase systems in endothelial cell migration. Endothelial cell migration alongside a denuded surface may, however, require other proteolytic mechanisms than invasion through anatomic barriers, as suggested by the deficient endothelial cell recruitment in u-PAdeficient mice after Polyoma middle T transformation (51).

Role of plasmin proteolysis in vascular wound healing. Gene targeting studies have demonstrated that the plasminogen system plays a more important role during conditions of inflammation and healing than during development or nonpathological conditions (50). An interesting question is thus whether the role of the plasminogen system depends on the severity of the injury or the extent of the tissue response, since a more severe injury would result in increased matrix deposition and require more plasmin proteolysis to remove this debris. In addition, a more severe injury may result in greater infiltration by leukocytes that can assist in migration of smooth muscle cells (see above). In this respect, it is noteworthy that accumulation of smooth muscle cells, but also of leukocytes, was reduced in $\mathrm{Plg}^{-1-}$ arteries (present study). It will thus be interesting to determine whether leukocytes are able to orchestrate the arterial response to injury not only by controlling mitogenic signals (3), but also by assisting migration of smooth muscle cells.

In conclusion, this study provides direct genetic proof that plasmin proteolysis promotes vascular wound healing and associated neointima formation in mice, most likely by promoting migration of smooth muscle cells into the wound.

\section{Acknowledgments}

The authors gratefully acknowledge the help of V. Attenburrow, A. Bouché, I. Cornelissen, C. Declercq, M. De Mol, M. Deprez, B. Hermans, and I. Van Vlaenderen.

This work was supported by a grant from the Human Frontiers in Science Program (RG-363/95) to P. Carmeliet, V. Ploplis, L. Moons, E. Plow, and D. Collen.

\section{References}

1. Schwartz, S.M., M.A. Reidy, and E.R.M. O'Brien. 1995. Assessment of factors important in atherosclerotic occlusion and restenosis. Thromb. Haemostasis. 74:541-551.

2. Ip, J.H., V. Fuster, D. Israel, L. Badimon, J. Badimon, and J.H. Cheseboro. 1991. The role of platelets, thrombin and hyperplasia in restenosis after coronary angioplasty. J. Am. Coll. Cardiol. 17:77-88.

3. Libby, P., D. Schwartz, E. Brogi, H. Tanaka, and S.K. Clinton. 1992. A cascade model for restenosis. A special case of atherosclerotic progression. Circulation. 86(Suppl. III):47-52.

4. Clowes, A.W., and M.A. Reidy. 1991. Prevention of stenosis after vascular reconstruction: pharmacologic control of intima hyperplasia-a review. $J$. Vasc. Surg. 13:885-889.

5. Reidy, M.A., D. Jackson, and V. Lindner. 1992. Neointimal proliferation: control of vascular smooth muscle cell growth. Vasc. Med. Rev. 3:156-167.

6. Clowes, A.W., M.M. Clowes, T.R. Kirkman, C.L. Jackson, Y.P. Au, and R. Kenagy. 1992. Heparin inhibits the expression of tissue-type plasminogen activator by smooth muscle cell in injured rat carotid artery. Circ. Res. 70:11281136.

7. Clowes, A.W., M.M. Clowes, Y.P. Au, M.A. Reidy, and D. Belin. 1990. Smooth muscle cells express urokinase during mitogenesis and tissue-type plasminogen activator during migration in injured rat carotid artery. Circ. Res. 67: 61-67.

8. Jackson, C.L., E.W. Raines, R. Ross, and M.A. Reidy. 1993. Role of endogenous platelet-derived growth factor in arterial smooth muscle cell migration after balloon catheter injury. Arterioscler. Thromb. 13:1218-1226.

9. Jackson, C.L., and M.A. Reidy. 1992. The role of plasminogen activation in smooth muscle cell migration after injury. Ann. N.Y. Acad. Sci. 667:141-150.

10. Reidy, M.A., C. Irvin, and V. Lindner. 1996. Migration of arterial wall cells. Expression of plasminogen activators and inhibitors in injured rat arteries. Circ. Res. 78:405-414.

11. van Leeuwen, R.T.J. 1996. Extracellular proteolysis and the migrating vascular smooth muscle cell. Fibrinolysis. 10:59-74.

12. Bendeck, M.P., N. Zempo, A.W. Clowes, R.E. Galardy, and M.A. Reidy. 1994. Smooth muscle cell migration and matrix metalloproteinase expression after arterial injury in the rat. Circ. Res. 75:539-545.

13. Dollery, C.M., J.R. McEwan, and A.M. Henney. 1995. Matrix metalloproteinases and cardiovascular disease. Circ. Res. 77:863-868.

14. Collen, D., and H.R. Lijnen. 1991. Basic and clinical aspects of fibrinolysis and thrombolysis. Blood. 78:3114-3124.

15. Vassalli, J.D. The urokinase receptor. 1994. Fibrinolysis. 8(Suppl. 1): $172-181$.

16. Dano, K., N. Behrendt, N. Brünner, V. Ellis, M. Ploug, and C. Pyke. 1994. The urokinase receptor. Protein structure and role in plasminogen activation and cancer invasion. Fibrinolysis. 8(Suppl. 1):189-203.

17. Saksela, O., and D. Rifkin. 1988. Cell-associated plasminogen activation: regulation and physiological function. Annu. Rev. Cell Biol. 4:93-126.

18. Matsushima, K., M. Taguchi, E.J. Kovacs, H.A Yound, and J.J. Oppenheim. 1986. Intracellular localization of human monocytic interleukin-1 (IL-1) activity and release of biologically active IL-1 from monocytes by trypsin and plasmin. J. Immunol. 136:2883-2891.

19. Bertozzi, P., B. Astedt, L. Zenzius, K. Lynch, F. LeMaire, W. Zapoli, and H.A. Chapman. 1990. Depressed bronchioalveolar urokinase activity in patients with adult respiratory distress syndrome. N. Engl. J. Med. 322:890-897.

20. Idell, S., K.K. James, E.G., Levin, B.S. Schwartz, N. Manchanda, R.J. Maunder, R.J. Martin, J. McLarty, and D.S. Fair. 1989. Local abnormalities in coagulation and fibrinolytic pathways predispose to alveolar fibrin deposition in the adult respiratory distress syndrome. J. Clin. Invest. 84:695-705.

21. Tomooka, S., W.A. Border, B.C. Marshall, and N.A. Noble. 1992 Glomerular matrix accumulation is linked to inhibition of the plasmin protease system. Kidney Int. 42:1462-1469.

22. Eitzman, D.T., R.D. McCoy, X. Zheng, W.P. Fay, T. Shen, and D. Ginsburg. 1996. Bleomycin-induced pulmonary fibrosis in transgenic mice that either lack or overexpress the murine plasminogen activator inhibitor-1 gene. $J$. Clin. Invest. 97:232-237.

23. Romer, J., T.H. Bugge, C. Pyke, L.R. Lund, M.J. Flick, J.L. Degen, and K. Dano. 1996. Impaired wound healing in mice with a disrupted plasminogen gene. Nat. Med. 2:287-292.

24. Kitching, A.R., P. Carmeliet, V. Ploplis, D. Collen, E. Plow, E.R. Holdsworth, and P. Tipping. 1996. Glomerulonephritis in mice with genetic deficiencies of the plasminogen systesm. J. Exp. Med. In press.

25. Quax, P.H.A., P. Koolwijk, J.H. Verheijen, and V.W.M. van Hinsbergh. 1996. Advances in vascular biology. In: Vascular Control of Hemostasis. V.W.M. van Hinsbergh, editor. Harwood Academic Publishers, UK. 227-245.

26. Fearns, C., F. Samad, and D.J. Loskutoff. 1996. Advances in vascular biology. In: Vascular Control of Hemostasis. V.W.M. van Hinsbergh, editor. Harwood Academic Publishers, U.K. 207-227.

27. Carmeliet, P., and D. Collen. 1995. Role of the plasminogen/plasmin system in thrombosis, hemostasis, restenosis and atherosclerosis. Evaluation in transgenic animals. Trends Cardiovasc. Med. 5:117-122.

28. Estreicher, A., J. Müllhauser, J.L. Carpentier, L. Orci, and J.D. Vassalli. 
1990. The receptor for urokinase type plasminogen activator polarizes expression of the protease to the leading edge of migrating monocytes and promotes degradation of enzyme inhibitor complexes. J. Cell Biol. 111:783-792.

29. Reuning, U., and N. Bang. 1992. Regulation of the urokinase-type plasminogen activator receptor on vascular smooth muscle cells is under the control of thrombin and other mitogens. Arterioscler. Thromb. 12:1161-1170.

30. Salame, M.Y., W. Martin, R.S. More, H. Mahadeva, and D.P. deBono. 1996. Time sequence of changes in vessel wall tissue-type plasminogen activator, urokinase-type plasminogen activator and its receptor following experimental angioplasty. Fibrinolysis. 10(Suppl.) 3:249a. (Abstr.)

31. Kanthou, C., S. Das, V.V. Kakkar, and F. Lupu. 1996. Expression of some components of plasminogen activation (PA) pathway by arterial segments in organ culture after in vitro injury. Fibrinolysis. 10(Suppl. 3):11a. (Abstr.)

32. Villaverde, C.A., M. Miralles, N. Salvat, O. Juan, N. Tibau, E. Pena, and P. Vigo. 1996. Regulation of plasmin-generating activity in human arteries. Fibrinolysis. 10(Suppl. 3):148a. (Abstr.)

33. Schneiderman, J., G.M. Bordin, I Engelberg, R. Adar, D. Seiffert, T. Thinnes, E.F. Bernstein, R.B. Dilley, and D.J. Loskutoff. 1995. Expression of fibrinolytic genes in atherosclerotic abdominal aortic aneurysm wall. J. Clin. Invest. 96:639-645.

34. Lupu, F., D.A. Heim, F. Bachmann, M. Hurni, V.V. Kakkar, and E.K.O. Kruithof. 1995. Plasminogen activator expression in human atherosclerotic lesions. Arterioscler. Thromb. Vasc. Biol. 15:1444-1455.

35. Dechend, R., S. Mo, C. Tamaschcke, W. Schulz, M. Gross, R. Dietz, and D. Gulba. 1996. Thrombin receptor and urokinase-type plasminogen activator are colocalized in vascular smooth muscle cells derived from human carotid atherosclerotic plaques. Fibrinolysis. 10(Suppl. 3):254a. (Abstr.)

36. Padro, T., M. Steins, C.X. Li, and J. Kienast. 1996. Urokinase plasminogen activator (u-PA) in human atherosclerotic coronary arteries. Fibrinolysis 10(Suppl. 3):10a. (Abstr.)

37. Ploplis, V., P. Carmeliet, S. Vazirzadeh, I. Van Vlaenderen, L. Moons, E. Plow, and D. Collen. 1995. Effects of disruption of the plasminogen gene on thrombosis, growth and health in mice. Circulation. 92:2582-2593.

38. Carmeliet, P., L. Moons, J.M. Stassen, I. Van Vlaenderen, C. Declercq, M. Kockx, and D. Collen. Vascular wound healing and neointima formation induced by perivascular injury in mice. Am. J. Pathol. In press.
39. Betz, E., and W. Schlote. 1979. Responses of vessel wall to chronically applied electric stimuli. Basic Res. Cardiol. 74:10-20.

40. Carmeliet, P., L. Schoonjans, L. Kieckens, B. Ream, J. Degen, R. Bronson, R. De Vos, J.J. van den Oord, D. Collen, and R.C. Mulligan. 1994. Physiological consequences of loss of plasminogen activator gene function in mice. Nature (Lond.). 368:419-423.

41. Astrup, T., and S. Müllertz. 1952. Arch. Biochem. Biophys. 40:346-351.

42. Lindner, V., J. Fingerle, and M.A. Reidy. 1993. Mouse model of arterial injury. Circ. Res. 73:792-796.

43. Clowes, A.W., M.A. Reidy, and M.M. Clowes. 1983. Mechanisms of stenosis after arterial injury. Lab. Invest. 49:208-215.

44. Clowes, A.W., M.A. Reidy, and M.M. Clowes. 1983. Kinetics of cellular proliferation after arterial injury. I. Smooth muscle growth in the absence of endothelium. Lab. Invest. 49:327-333.

45. Kockx, M., B.A. Cambier, H.E. Bortier, G.R. De Meyer, and P.A. Van Cauwelaert. 1992. The modulation of smooth muscle cell phenotype is an early event in human athero-coronary saphenous vein grafts. Virchow's Archiv. Pathol. Anat. Histopathol.

46. Dilley, R.J., J.K. McGeachie, and M. Tennant. 1992. The role of cell proliferation and migration in the development of a neo-intimal layer in vein grafted into arteries, in rats. Cell Tissue Res. 269:281-287.

47. Douek, P.C., R. Correa, R. Neville, E.F. Unger, M. Shou, S. Banai, V.J. Ferrans, S.E. Epstein, M.B. Leon, and R.F. Bonner. 1992. Dose-dependent smooth muscle cell proliferation induced by thermal injury with pulsed infrared lasers. Circulation. 86:1249-1256.

48. Glagov, S., and C. T'sao. 1975. Restitution of aortic wall after sustained necrotizing transmural ligation injury. Am. J. Pathol. 79:7-30.

49. Serure, A., E.H. Wither, S. Thomson, and J. Morris. 1986. Comparison of carbon dioxide laser assisted anastomosis and conventional microvascular sutured anastomosis. Surg. Forum. 34:634-636.

50. Carmeliet, P., and D. Collen. 1996. Gene manipulation and transfer of the plasminogen system and coagulation system in mice. Sem. Thromb. Hemostasis. In press.

51. Wagner, E., K.T. Sabapathy, F. Kiefer, U. Möhle-Steinlein, F. TacchiniCottier, I. Fetka, G. Breier, P. Carmeliet, W. Risau, R. Montesano, and M. Pep per. Polyoma middle T-induced vascular tumor formation: the role of the plasminogen activator/plasmin system. J. Cell Biol. In press. 